\title{
Reproductive biology traits affecting productivity of sour cherry
}

\author{
Milica Fotirić Akšić(1), Vera Rakonjac (1), Dragan Nikolić(1) and Gordan Zec ${ }^{(1)}$ \\ (1)University of Belgrade, Faculty of Agriculture, Nemanjina 6, 11080 Belgrade, Serbia. E-mail: fotiric@agrif.bg.ac.rs, verak@agrif.bg.ac.rs, \\ nikolicd@agrif.bg.ac.rs, zecg2004@yahoo.com
}

\begin{abstract}
The objective of this work was to evaluate variability in reproductive biology traits and the correlation between them in genotypes of 'Oblačinska' sour cherry (Prunus cerasus). High genetic diversity was found in the 41 evaluated genotypes, and significant differences were observed among them for all studied traits: flowering time, pollen germination, number of fruiting branches, production of flower and fruit, number of flowers per bud, fruit set, and limb yield efficiency. The number of fruiting branches significantly influenced the number of flower and fruit, fruit set, and yield efficiency. In addition to number of fruiting branches, yield efficiency was positively correlated with fruit set and production of flower and fruit. Results from principal component analysis suggested a reduction of the reproductive biology factors affecting yield to four main characters: number and structure of fruiting branches, flowering time, and pollen germination. Knowledge of the reproductive biology of the 'Oblačinska' genotypes can be used to select the appropriate ones to be grown or used as parents in breeding programs. In this sense, genotypes II/2, III/9, III/13, and III/14 have very good flower production and satisfactory pollen germination.
\end{abstract}

Index terms: Prunus cerasus, breeding, genetic divergence, pollen germination, principal component analysis, yield efficiency.

\section{Características da biologia reprodutiva que afetam a produtividade de cereja ácida}

Resumo - O objetivo deste trabalho foi avaliar a variabilidade de características da biologia reprodutiva e a correlação entre elas, em genótipos da cereja ácida (Prunus cerasus) 'Oblačinska'. Verificou-se alta diversidade genética nos 41 genótipos avaliados, e foram observadas diferenças significativas entre eles, para todas as características estudadas: época de florescimento, germinação de pólen, número de ramos frutíferos, produção de flores e frutos, número de flores por botão, formação de frutos e eficiência de produção dos ramos. O número de ramos frutíferos influenciou significativamente o número de flores e frutos, a formação de frutos e a eficiência produtiva. Além do número de ramos frutíferos, a eficiência produtiva correlacionou-se positivamente com o pegamento de frutos e a produção de flores e frutos. Os resultados da análise de componentes principais sugerem a redução dos fatores de biologia reprodutiva que afetam a produtividade a quatro características principais: número e estrutura dos ramos frutíferos, tempo de florescimento e germinação de pólen. O conhecimento da biologia floral dos genótipos 'Oblačinska' pode ser útil para a escolha dos mais apropriados para plantio ou uso como parentais em programas de melhoramento. Neste sentido, os genótipos II/2, III/9, III/13 e III/14 apresentam produção de flores muito boa e germinação de pólen satisfatória.

Termos para indexação: Prunus cerasus, melhoramento, divergência genética, germinação de pólen, análise de componentes principais, eficiência produtiva.

\section{Introduction}

Sour cherry (Prunus cerasus L.) is one of the most commercially important fruit species worldwide, and Serbia is among the top five producing countries (Pérez-Sánchez et al., 2008). Sour cherry belongs to the group of medium, early-blooming fruit trees, but is the latest among stone fruits (Nyeki et al., 2002). In Serbian orchards, the 'Oblačinska' sour cherry is the most planted, because of its positive characteristics, such as high fruit quality, small size, self-fertility, and high demand in domestic and foreign fruit markets.
Oblačinska sour cherry is an autochthonous cultivar and represents a heterogeneous population, which is a mixture of numerous genotypes. According to several authors, who studied 'Oblačinska' populations, the highest variability among genotypes was mainly found in pomological and technological traits, including maturing time, yield, size, and fruit quality (Milutinović et al., 1980; Nikolić et al., 2005; Rade et al., 2008; Rakonjac etal., 2010). Therefore, genotype selection is recommended in order to allocate suitable genotypes for commercial production or breeding. 
A top-priority task in many breeding programs is increasing yield. However, Kodad \& Socias i Company (2008) observed that the potential crop value of fruit trees is difficult to estimate, since many factors influence final yield and quality. These factors are both genetic and environmental, and are further affected by their interaction.

Reproductive biology certainly plays an important role on yield. According to Garcia-Montiel et al. (2010), many factors related to cherry floral biology influence productivity, such as flower bud density, number of flowers per bud, number of flowering nodes per branch, flower bud drop, flower quality or fruit set. Chang et al. (1987) found that the number of reproductive buds and fruit sets are the most significant yield components in Montmorency and Meteor cultivars. Important direct and indirect effects of number of flower buds, number of flowers, and initial fruit set on yield in the 'Oblačinska' sour cherry was estimated by Rakonjac \& Nikolić (2008). Socias i Company et al. (2004) also reported that the estimation of bloom density and fruit set of any genotype is an important step in the evaluation of its productive potential and of its value as a commercial cultivar.

The number of flowers that differentiated during the previous season is the first yield component in fruit trees. The term "flower quality" has been coined to explain differences among flowers in their capacity to set fruit (Williams, 1965), but the causes underpinning these differences are largely unknown. Szpadzik et al. (2008) cited that flower pollination has a main role in fruit set, in sour cherries. Some biological features of sour cherries - low cultivar fertility, short flower pollination period, and low pollen quality - decrease the effectiveness of pollination and cause poor fruit set. For a successful fertilization, pollen must have good functional ability, which requires adequate vitality and satisfactory germination. Internal causes in the flower have also been related to fruit set, such as nutritional status (Rodrigo et al., 2009) and stage of development of the ovule or the embryo sac at anthesis (Burgos et al., 2004; Ansari \& Davarynejad, 2008). This depends on the biology of each cultivar (Kodad \& Socias i Company, 2004) or on the environmental factors during and after bloom. Low fruit set has been attributed to frost (Gunes, 2006) and high pre-blossom temperatures (Rodrigo \& Herrero, 2002). Furthermore, the overall energy balance of the plant may also play an important role in fruit set (Ebert, 2009). Besides directly affecting the number of fruits and yield, reproductive biology traits can affect the weight and fruit quality of cherry (Davarynejad et al., 2008).

In agricultural sciences, in which complex data sets with different variables are often used, the application of multivariate statistics is fundamental, and principal component analysis (PCA) is mostly applied to reduce the number of input variables (Uno et al., 2005). Previously, PCA has been used to evaluate different cherry collections (Hillig \& Iezzoni, 1988; Hjalmarsson \& Ortiz, 2000; Beyer et al., 2002; Rakonjac et al., 2010).

The objective of this work was to evaluate the variability in reproductive biology traits (flowering time, pollen germination, number of fruiting branches, flower and fruit production, number of flowers per bud, fruit set, and limb yield efficiency) and the correlation between them in 41 'Oblačinska' sour cherry genotypes.

\section{Materials and Methods}

The 41 'Oblačinska' sour cherry genotypes used in this experiment are part of the 560 accessions collected from different regions of Serbia and maintained at the Radmilovac Experimental Station, located $8 \mathrm{~km}$ North-East of Belgrade $\left(44^{\circ} 45^{\prime} \mathrm{N}\right.$ and $20^{\circ} 35^{\prime} \mathrm{E}$, at $135 \mathrm{~m}$ altitude), which belongs to the Faculty of Agriculture of the University of Belgrade. The collection orchard, which includes one tree of each selected genotype, was established in 1993 and was 11 years old at the beginning of the experiment. Planting distance was $4 \times 2 \mathrm{~m}$. The soil is classified as Eutric Cambisol. The trees were trained as spindle bush, under non-irrigated standard cultural practices.

The experiment was set as a randomized complete block design with three replicates. Data were collected over three consecutive years (2004-2006). The same three branches were selected and marked, on each genotype, for trait analysis during the experimental period. Although the genotypes have different branching habits, all limbs were selected as homogeneously as possible, including cardinally -oriented branches with different directions around the canopy. Approximate branch length was $1 \mathrm{~m}$, placed at about $1.5 \mathrm{~m}$ over the ground. The results obtained from those branches were used to calculate the average for each genotype in each experimental year

Pesq. agropec. bras., Brasília, v.48, n.1, p.33-41, jan. 2013 DOI: 10.1590/S0100-204X2013000100005 
and for all studied traits. The year of the experiment was taken as a repetition. The following traits were analyzed: flowering time (FT), pollen germination (PG), fruiting branch production (FBP), percentage of spurs (SP), percentage of shoots (SH), number of flowers per fruiting bud (FL/FP), flower production (FLP), fruit production (FRP), fruit set (FS) and limb yield efficiency (LYE).

The flowering time of each individual genotype was recorded visually, considered as the day when approximately $80 \%$ of the flowers were open. For statistical analysis, flowering time was represented as the number of days counting from April 1.

Pollen was freshly gathered from 20 flowers from each marked branch at the balloon stage (1-2 days before opening). Anthers were removed and stored at $20^{\circ} \mathrm{C}$ for 24 hours. In vitro germinability of freshly collected pollen was tested on a germination medium containing agar $(0.3 \%)$ and sucrose $(14 \%)$. At least 500 pollen grains were observed and counted, and the germination rate was calculated. When the length of the pollen tube exceeded its diameter, the pollen was considered germinated.

Limb circumference was measured at the base of the limb and used to estimate limb cross-sectional area (LCSA). During the experiment, three limbs per genotype were selected for measurements. The number of fruiting branches was counted in each of the three limbs and used to determine fruiting branch production, expressed as fruiting branch per $\mathrm{cm}^{2}$ LCSA. The percentage of both shoots and spurs was also calculated. During anthesis, the number of flowers per fruiting bud was counted together with the total number of flowers produced (number of flowers per $\mathrm{cm}^{2}$ LCSA). The branches were left for open pollination, and the number of fruits on the same branch was counted in June, from which fruit production (number of fruits per $\mathrm{cm}^{2}$ LCSA) and fruit set percentage (number of fruits per total remaining flowers) were calculated as an expression of productivity and flower quality, respectively. Total harvested yield per limb was recorded at commercial harvest time, when limb yield efficiency was calculated as the ratio between yield and LSCA and expressed in $\mathrm{kg} \mathrm{cm}^{-2}$.

Statistical analyses (analysis of variance, correlation analysis, and PCA) were performed with the software Statistica (StatSoft, Inc., Tulsa, OK, USA). Analysis of variance was applied to distinguish the effect of the genotype and of the year on the studied traits; correlation analysis was performed using the Pearson correlation coefficients to show the relationships among the traits; and PCA was used to identify the most significant variables in the data set and to perform a simplified classification of the 'Oblačinska' sour cherry genotypes in terms of measured variables.

\section{Results and Discussion}

Flowering time ranged from April 13 (XI/22) to April $20(\mathrm{~V} / 10)$, although most of the genotypes flowered during April 16 and 17 (Table 1). Since flowering is a phenotypically related process in which environmental factors and genotypic traits have considerable effects on blooming (Davarynejad et al., 2009), significant differences among genotypes and year-by-year variation were expected.

Pollen germination percentage ranged between 48.70 (VII/3) and 85.84\% (II/16). Most of the evaluated genotypes showed pollen germination higher than $70 \%$, which is more than adequate for pollination. Only genotypes XIII/1, XI/3, and VII/3 showed values lower than $55 \%$, which is still enough for adequate pollination. Differences between years were found (Table 2). 'Oblačinska' sour cherry has a high percentage of pollen germination when compared to other varieties (Davarynejad et al., 2008) and it could be a good pollen donor for other cultivars. The pollen germination range reported here is higher than the ones obtained by Tosun \& Koyuncu (2007) and Szpadzik et al. (2010), which was of ca. $57 \%$.

The production of fruiting branch was highly variable (Table 1), with mean values ranging from 2.09 to 11.24 . The percentage of spurs or shoots in the total number of fruiting branches showed a wide range, from 34.37 to $70.83 \%$ and from 29.50 to $65.63 \%$, respectively. Fructification on spurs in sour cherry increases the productive surface and extends the productive period for several years, as previously reported by Alburquerque et al. (2004) for apricot. Since high variation was determined between genotypes and years (Table 2), it is expected that those two traits should be further studied to determine whether they are more influenced by genetic or environmental factors.

The number of flowers per fruiting bud ranged from 2.7 (III/1) to 3.8 (IV/8). Analysis of variance showed significant differences between genotypes and years 
(Table 2). According to Kodad \& Socias i Company (2004) it is advisable to select genotypes with a high ratio between flowers and buds when there is risk of late spring frost, since a high number of flowers may compensate frost damages and permit acceptable yields.
A large variability was also observed for the other traits, including flower production, which ranged from 36.32 to 158.26 flowers per $\mathrm{cm}^{2}$ LCSA (Table 1). Genotypes with high flower production had more than 100 flowers per $\mathrm{cm}^{2}$ (II/2, II/6, II/10, III/9, III/13,

Table 1. Average values of flowering time, pollen germination, fruiting branch production (FBP), percentage of spurs, percentage of shoots, number of flowers per fruiting bud, flower production, fruit production, fruit set, and limb yield efficiency in 41 'Oblačinska' genotypes.

\begin{tabular}{|c|c|c|c|c|c|c|c|c|c|c|}
\hline Genotype & $\begin{array}{l}\text { Flowering } \\
\text { time }\end{array}$ & $\begin{array}{c}\text { Pollen } \\
\text { germination } \\
(\%)\end{array}$ & $\left(\right.$ per $\left.\mathrm{cm}^{2}\right)$ & ----- & ----- & $\begin{array}{l}\text { Flower per } \\
\text { fruiting bud }\end{array}$ & $\begin{array}{c}\text { Flower } \\
\text { production }\end{array}$ & $\begin{array}{c}\text { Fruit } \\
\text { production } \\
\text { er } \mathrm{cm}^{2} \mathrm{LCS} A\end{array}$ & $\begin{array}{l}\text { Limb yield } \\
\text { efficiency }\end{array}$ & $\begin{array}{c}\text { Fruit set } \\
(\%)\end{array}$ \\
\hline $\mathrm{I} / 1$ & 17 April & 72.48 & 4.66 & 50.50 & 49.50 & 3.1 & 91.12 & 28.39 & 0.118 & 51.8 \\
\hline $\mathrm{II} / 2$ & 16 April & 81.95 & 8.63 & 54.07 & 45.93 & 3.0 & 118.11 & 45.63 & 0.180 & 59.4 \\
\hline $\mathrm{II} / 6$ & 16April & 84.10 & 6.81 & 57.47 & 42.53 & 3.1 & 114.23 & 32.67 & 0.136 & 57.4 \\
\hline II/10 & 16 April & 60.78 & 8.76 & 60.27 & 39.73 & 3.2 & 113.93 & 42.06 & 0.161 & 58.7 \\
\hline II/16 & 15 April & 85.84 & 5.93 & 53.67 & 46.33 & 3.3 & 92.66 & 32.26 & 0.140 & 57.8 \\
\hline III/1 & 18April & 66.79 & 8.54 & 64.07 & 35.93 & 2.7 & 95.97 & 22.27 & 0.080 & 42.0 \\
\hline III/9 & 17 April & 80.58 & 11.24 & 54.30 & 45.70 & 3.0 & 158.26 & 61.62 & 0.216 & 64.2 \\
\hline III/13 & 17 April & 74.62 & 6.30 & 48.73 & 51.27 & 2.9 & 100.64 & 36.07 & 0.143 & 56.4 \\
\hline III/14 & 16 April & 72.16 & 7.81 & 68.97 & 31.03 & 3.0 & 118.89 & 47.00 & 0.168 & 51.4 \\
\hline III/17 & 16April & 77.43 & 4.84 & 63.67 & 36.33 & 3.0 & 81.47 & 24.73 & 0.093 & 48.5 \\
\hline IV/1 & 18 April & 69.40 & 4.02 & 54.93 & 45.07 & 3.1 & 56.68 & 22.02 & 0.085 & 57.9 \\
\hline IV/8 & 17 April & 66.86 & 4.13 & 40.50 & 59.50 & 3.8 & 49.39 & 13.72 & 0.059 & 48.6 \\
\hline IV/17 & 17 April & 78.92 & 3.67 & 41.70 & 58.30 & 2.9 & 36.72 & 14.23 & 0.052 & 60.8 \\
\hline IV/19 & 15 April & 71.52 & 2.09 & 36.90 & 63.10 & 3.2 & 53.69 & 17.50 & 0.068 & 49.5 \\
\hline $\mathrm{IV} / 5 \mathrm{~N}$ & 15 April & 82.49 & 4.18 & 34.37 & 65.63 & 3.4 & 81.05 & 17.09 & 0.075 & 51.3 \\
\hline $\mathrm{V} / 2$ & 18 April & 56.66 & 5.69 & 48.90 & 51.10 & 3.1 & 117.98 & 26.29 & 0.114 & 52.5 \\
\hline $\mathrm{V} / 6$ & 17 April & 72.38 & 4.00 & 42.30 & 57.70 & 3.6 & 82.50 & 28.87 & 0.120 & 60.2 \\
\hline $\mathrm{V} / 10$ & 20 April & 67.13 & 6.80 & 55.87 & 44.13 & 3.1 & 72.90 & 23.35 & 0.082 & 57.2 \\
\hline $\mathrm{V} / 29$ & 14 April & 74.22 & 4.89 & 50.30 & 49.70 & 3.5 & 82.96 & 16.39 & 0.068 & 42.1 \\
\hline $\mathrm{VI} / 27$ & 14 April & 74.58 & 6.02 & 39.07 & 60.93 & 3.1 & 91.13 & 20.60 & 0.093 & 42.9 \\
\hline $\mathrm{VI} / 28$ & 15 April & 72.42 & 7.97 & 48.73 & 51.27 & 3.3 & 107.88 & 22.06 & 0.091 & 34.8 \\
\hline $\mathrm{VII} / 3$ & 16April & 48.70 & 3.72 & 66.47 & 33.53 & 3.2 & 54.95 & 19.50 & 0.086 & 55.2 \\
\hline VII/14 & 16 April & 71.50 & 7.59 & 59.33 & 40.67 & 3.2 & 82.18 & 13.07 & 0.058 & 46.5 \\
\hline $\mathrm{VII} / 2 \mathrm{~N}$ & 14 April & 66.67 & 3.21 & 55.20 & 44.80 & 3.4 & 85.33 & 14.17 & 0.061 & 44.4 \\
\hline VIII/7 & 17 April & 78.73 & 2.93 & 49.80 & 50.20 & 3.1 & 51.87 & 10.10 & 0.047 & 42.6 \\
\hline VIII/15 & 17 April & 75.39 & 3.27 & 70.83 & 29.17 & 3.0 & 48.00 & 15.75 & 0.071 & 47.0 \\
\hline VIII/10N & 15 April & 76.88 & 2.82 & 63.10 & 36.90 & 3.4 & 63.13 & 14.69 & 0.063 & 40.5 \\
\hline IX/13 & 16 April & 67.29 & 3.77 & 53.60 & 46.40 & 3.0 & 70.93 & 18.66 & 0.079 & 44.9 \\
\hline IX/P & 15 April & 57.44 & 4.58 & 51.60 & 48.40 & 3.2 & 151.70 & 41.05 & 0.175 & 46.4 \\
\hline $\mathrm{X} / 11$ & 16 April & 62.40 & 3.49 & 54.23 & 45.77 & 3.3 & 60.85 & 13.59 & 0.052 & 54.5 \\
\hline $\mathrm{XI} / 2$ & 16 April & 74.46 & 6.39 & 57.47 & 42.53 & 3.1 & 62.38 & 26.78 & 0.109 & 45.4 \\
\hline $\mathrm{XI} / 3$ & 17 April & 54.89 & 3.36 & 70.50 & 29.50 & 2.9 & 68.58 & 15.83 & 0.083 & 42.2 \\
\hline $\mathrm{XI} / 22$ & 13 April & 69.08 & 2.92 & 60.37 & 39.63 & 3.3 & 65.84 & 10.98 & 0.044 & 34.7 \\
\hline $\mathrm{XII} / 2$ & 17 April & 78.56 & 3.51 & 66.33 & 33.67 & 2.9 & 81.44 & 21.88 & 0.088 & 47.0 \\
\hline $\mathrm{XII} / 13$ & 17 April & 81.32 & 3.10 & 51.03 & 48.97 & 3.1 & 48.56 & 8.56 & 0.036 & 36.1 \\
\hline XIII/1 & 17 April & 52.94 & 3.47 & 55.00 & 45.00 & 3.1 & 36.32 & 8.84 & 0.038 & 43.9 \\
\hline $\mathrm{XIII} / 4$ & 18 April & 73.67 & 3.61 & 52.53 & 47.47 & 3.1 & 40.58 & 13.11 & 0.053 & 52.1 \\
\hline $\mathrm{XIII} / \mathrm{P}$ & 16 April & 64.02 & 6.63 & 58.83 & 41.17 & 3.2 & 95.25 & 23.33 & 0.096 & 43.2 \\
\hline $\mathrm{XIV} / 5$ & 18April & 65.23 & 5.70 & 70.83 & 29.17 & 3.1 & 70.64 & 17.29 & 0.077 & 41.6 \\
\hline XV/1 & 15 April & 65.19 & 5.20 & 55.13 & 44.87 & 3.3 & 98.08 & 20.23 & 0.078 & 49.5 \\
\hline $\mathrm{XV} / 8$ & 15 April & 68.57 & 5.66 & 55.53 & 44.47 & 2.9 & 71.01 & 28.88 & 0.116 & 55.4 \\
\hline
\end{tabular}

LCSA, limb cross-sectional area. 
III/14, V/2, VI/28, and IX/P). Only the genotypes IV/8, IV/17, VIII/15, XII/13, XIII/1, and XIII/4 showed less than 50 flowers per $\mathrm{cm}^{2}$. Fruit production ranged between 8.56 and 61.62 fruits per $\mathrm{cm}^{2}$ for most of the genotypes, although genotypes II/2, II/10, III/9, III/14, and IX/P showed values lower than 40 fruits per $\mathrm{cm}^{2}$. The year-by-year variation significantly affected flower production, as indicated by analysis of variance (Table 2). Results showed a high productivity potential for most of the studied genotypes. Only

Table 2. Summary of the analysis of variance for the reproductive biology traits of 'Oblačinska' sour cherry.

\begin{tabular}{|c|c|c|c|c|}
\hline Variable & df & Mean square & F-value & p-value \\
\hline & \multicolumn{4}{|c|}{ Flowering time } \\
\hline Genotype & 40 & 5.62 & 5.05 & 0.000 \\
\hline Year & 2 & 355.52 & 319.71 & 0.000 \\
\hline \multirow[t]{2}{*}{ Error } & 80 & 1.11 & - & - \\
\hline & \multicolumn{4}{|c|}{ Pollen germination } \\
\hline Genotype & 40 & 227.67 & 3.41 & 0.000 \\
\hline Year & 2 & 447.52 & 6.70 & 0.002 \\
\hline \multirow[t]{2}{*}{ Error } & 80 & 66.72 & - & - \\
\hline & \multicolumn{4}{|c|}{ Fruiting branch production } \\
\hline Genotype & 40 & 12.68 & 1.62 & 0.035 \\
\hline Year & 2 & 239.07 & 30.49 & 0.000 \\
\hline \multirow[t]{2}{*}{$\begin{array}{l}\text { Error } \\
\end{array}$} & 80 & 7.84 & - & - \\
\hline & \multicolumn{4}{|c|}{ Percentage of spurs } \\
\hline Genotype & 40 & 247.88 & 8.82 & 0.000 \\
\hline Year & 2 & 546.89 & 19.46 & 0.000 \\
\hline \multirow[t]{2}{*}{ Error } & 80 & 28.10 & - & - \\
\hline & \multicolumn{4}{|c|}{ Percentage of shoots } \\
\hline Genotype & 40 & 247.88 & 8.82 & 0.000 \\
\hline Year & 2 & 546.89 & 19.46 & 0.000 \\
\hline \multirow[t]{2}{*}{ Error } & 80 & 28.10 & - & - \\
\hline & \multicolumn{4}{|c|}{ Number of flowers per fruiting bud } \\
\hline Genotype & 40 & 0.128 & 1.94 & 0.006 \\
\hline Year & 2 & 0.307 & 4.64 & 0.012 \\
\hline \multirow[t]{2}{*}{ Error } & 80 & 0.066 & - & - \\
\hline & \multicolumn{4}{|c|}{ Flower production } \\
\hline Genotype & 40 & $2,471.83$ & 1.90 & 0.007 \\
\hline Year & 2 & $3,851.82$ & 2.97 & 0.057 \\
\hline \multirow[t]{2}{*}{ Error } & 80 & $1,296.52$ & - & - \\
\hline & \multicolumn{4}{|c|}{ Fruit production } \\
\hline Genotype & 40 & 401.46 & 3.39 & 0.000 \\
\hline Year & 2 & $1,414.75$ & 11.96 & 0.000 \\
\hline \multirow[t]{2}{*}{ Error } & 80 & 118.29 & - & - \\
\hline & \multicolumn{4}{|c|}{ Fruit set } \\
\hline Genotype & 40 & 161.90 & 1.90 & 0.008 \\
\hline Year & 2 & $1,401.77$ & 164.58 & 0.000 \\
\hline \multirow[t]{2}{*}{ Error } & 80 & 85.20 & - & - \\
\hline & \multicolumn{4}{|c|}{ Limb yield efficiency } \\
\hline Genotype & 40 & 0.0054 & 3.36 & 0.000 \\
\hline Year & 2 & 0.0276 & 17.10 & 0.000 \\
\hline Error & 80 & 0.0016 & - & - \\
\hline
\end{tabular}

genotypes XII/13 and XIII/1, which presented fruit production lower than ten fruits per $\mathrm{cm}^{2}$ LCSA, showed productivity problems. The high number of floral biology factors affecting final fruiting and climatic conditions explains the differences between genotypes and the year-by-year variation concerning fruit production, as previously observed by Ruiz \& Egea (2008) for peach.

Fruit set percentages ranged between 34.8 (VI/28) and $64.2 \%$ (III/9) (Table 1). Besides genotypes, the evaluated years had also a significant effect on fruit set. Therefore, fruit set is partially controlled by genetic factors, but it is also affected by other factors, as shown for apricot (Alburquerque et al., 2004).

Limb yield efficiency also varied between genotypes, ranging from $0.036 \mathrm{~kg} \mathrm{~cm}^{-2}$, for genotype XII/13, to $0.216 \mathrm{~kg} \mathrm{~cm}^{-2}$ for genotype III/9 (Table 1). Besides III/9, the genotypes II/2, II/10, and IX/P also figured among the ones regarded as very productive, with limb yield efficiency over $0.150 \mathrm{~kg} \mathrm{~cm}^{-2}$. Low efficiency $\left(<0.060 \mathrm{~kg} \mathrm{~cm}^{-2}\right)$ was estimated in nine genotypes that had productivity problems. Analysis of variance showed significant differences among the genotypes for this trait and between the studied years (Table 2).

Flowering time and production from fruiting branches were significantly correlated (Table 3). In general, late-flowering genotypes showed a higher number of fruiting branches than early-flowering ones. However, there was significant negative correlation between pollen germination and flowering time, in which late-flowering genotypes showed, in general, lower pollen viability than early-flowering ones, which was also observed in apricot (Ruiz \& Egea, 2008). Pollen germination was not correlated with fruit set or limb yield efficiency, probably due to the open pollination of 'Oblačinska' sour cherry genotypes in this collection.

Production from fruiting branches was highly correlated with flower production, fruit production, fruit set, and limb yield efficiency. These correlations indicate that the higher the number of fruiting branches in these genotypes, the higher the flower production and the possibility of fertilization of these flowers, which would ensure a good level of fruit set and, consequently, a high commercial crop. Similar results were found with almond by Kodad \& Socias i Company (2004).

The correlation matrix showed that the percentage of both spurs and shoots had no influence on flower 
production, fruit production, fruit set, and limb yield efficiency (Table 3), independently of the number of floral buds per spur, which depends on it position along the shoot, increasing distally along two-, three-, and four-year-old shoots (Maguylo et al., 2004). A significant correlation between flower and fruit production was observed, as well as a negative but non-significant correlation between flower production and fruit set, which is in agreement with Ruiz \& Egea (2008) who reported the same results in apricot. Since the production of an adequate amount of flowers is one basis for a maximum crop yield, a positive correlation between flower production and limb yield efficiency was detected. All variables related to fruit production, fruit set, and limb yield efficiency were correlated with each other.

The first five principal components were enough to explain more than $90 \%$ of the total variability observed, with PC1, PC2, PC3, PC4, and PC5 accounting for $38.08,24.43,13.52,9.49$, and $6 \%$ of variance, respectively (Table 4). The production of flowers and fruit were the variables, besides yield, with higher scores on PC1 (over 0.70 of absolute value). The summarization of these traits in one component reflected the strong correlation between them reciprocally. The highest contribution of PC2 corresponded to the structure of the fruiting branches, which is the proportion of spurs to shoots. In PC3, flowering time was the most significant. Finally, the largest scores of PC4 were due to pollen germination. This result suggests that it is possible to reduce the studied reproductive biology factors affecting yield to four main characters: number and structure of fruiting branches, flowering time, and pollen germination.

In general, the 'Oblačinska' genotypes had their yields positively correlated with the number of fruiting branches, and, consequently, with the number of flowers and fruit, in all three scatter plots (Figure 1). The evaluated genotypes are situated at the extremes of PC1, representing their difference in the largest properties.

Table 3. Correlation matrix among evaluated traits.

\begin{tabular}{|c|c|c|c|c|c|c|c|c|c|}
\hline Variable & PG & FBP & $\mathrm{SP}$ & $\mathrm{SH}$ & $\mathrm{FL} / \mathrm{FP}$ & FLP & FRP & FS & LYE \\
\hline FT & $-0.189 *$ & $-0.316^{* *}$ & -0.164 & 0.164 & -0.038 & -0.029 & -0.121 & -0.095 & $-0.205^{*}$ \\
\hline PG & & 0.072 & -0.096 & 0.096 & -0.064 & 0.107 & 0.112 & -0.052 & 0.116 \\
\hline FBP & & & 0.155 & -0.155 & -0.058 & $0.340 * *$ & $0.612 * *$ & $0.414 * *$ & $0.620 * *$ \\
\hline $\mathrm{SP}$ & & & & $-1.000 * *$ & $-0.274^{*}$ & 0.062 & 0.100 & -0.061 & 0.117 \\
\hline $\mathrm{SH}$ & & & & & $0.274 *$ & -0.062 & -0.100 & 0.061 & -0.117 \\
\hline $\mathrm{FL} / \mathrm{FP}$ & & & & & & 0.112 & 0.052 & 0.071 & 0.046 \\
\hline FLP & & & & & & & $0.682 * *$ & -0.141 & $0.681 * *$ \\
\hline FRP & & & & & & & & $0.365^{* *}$ & $0.981 * *$ \\
\hline FS & & & & & & & & & $0.365 * *$ \\
\hline
\end{tabular}

*and**Significant at 5 and $1 \%$ probability, respectively. FT, flowering time; PG, pollen germination; FBP, fruiting branch production; SP, percentage of spurs; SH, percentage of shoots; FL/FP, number of flowers per fruiting bud; FLP, flower production; FRP, fruit production; FS, fruit set; and LYE, limb yield efficiency.

Table 4. Eigenvalues, proportion of total variability, and correlation between the original variables and the first five principal components.

\begin{tabular}{|c|c|c|c|c|c|}
\hline Variable & PC1 & PC2 & PC3 & PC4 & PC5 \\
\hline Flowering time & 0,121 & $-0,350$ & 0,817 & $-0,157$ & $-0,126$ \\
\hline Pollen germination & 0,160 & 0,400 & 0,121 & 0,848 & 0,222 \\
\hline Fruiting branch production & 0,836 & $-0,020$ & $-0,067$ & 0,054 & $-0,249$ \\
\hline Percentage of spurs & 0,165 & $-0,934$ & $-0,190$ & 0,059 & 0,239 \\
\hline Percentage of shoots & $-0,165$ & 0,934 & 0,190 & $-0,059$ & $-0,239$ \\
\hline Flowers per fruiting bud & $-0,339$ & 0,545 & $-0,370$ & $-0,365$ & 0,374 \\
\hline Flower production & 0,848 & 0,140 & $-0,370$ & $-0,079$ & $-0,183$ \\
\hline Fruit production & 0,971 & 0,107 & $-0,044$ & $-0,045$ & 0,078 \\
\hline Fruit set & 0,569 & 0,270 & 0,556 & $-0,219$ & 0,416 \\
\hline Limb yield efficiency & 0,956 & 0,117 & $-0,089$ & $-0,073$ & 0,082 \\
\hline Eigenvalue & 3,808 & 2,443 & 1,352 & 0,949 & 0,600 \\
\hline Total variance $(\%)$ & 38.08 & 24.42 & 13.52 & 9.49 & 6.00 \\
\hline Cumulative variance $(\%)$ & 38.08 & 62.51 & 76.03 & 85.52 & 91.52 \\
\hline
\end{tabular}



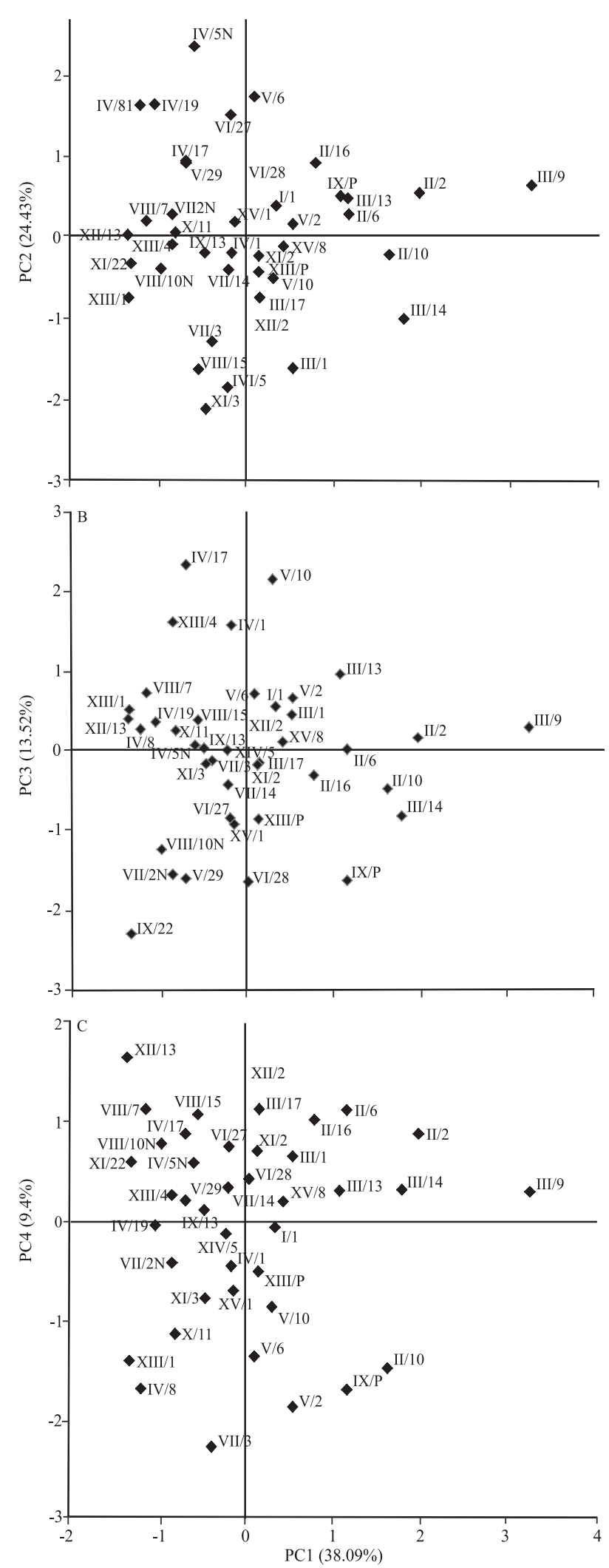

Figure 1. Two-dimensional scatter plots for A, PC1/PC2; B, $\mathrm{PC} 1 / \mathrm{PC} 3$; and $\mathrm{C}, \mathrm{PC} 1 / \mathrm{PC} 4$ of reproductive biology factors and productivity of 41 'Oblačinska' sour cherry genotypes.
Starting from the negative towards the positive values of $\mathrm{PC} 2$, the genotypes were characterized by an increase in the proportion of shoots, while reducing the share of the spurs in the total number of fruiting branches. From negative to positive values of PC3, genotypes were characterized by later flowering time. From negative to positive values of PC4, the genotypes decreased in percent of pollen germination.

The dispersed distribution of genotypes in the plots indicates high genetic diversity in the evaluated set of 'Oblačinska' sour cherry genotypes. Genotypes II/2, III/9, III/13, and III/14 stood out as the most promising ones, as can be seen in the scatter plots. These genotypes, beside high yield and good flower quality, had approximately the same number of shoots and spurs and were characterized by moderate to high pollen germination.

\section{Conclusions}

1. 'Oblačinska' sour cherry genotypes have high genetic variability in traits related to reproductive biology, and both genetic and environmental factors have high influence on these parameters.

2 . Fruiting branch production is highly correlated with flower and fruit production, and represents the most important reproductive biology trait that influences yield.

3. Reproductive biology of the 'Oblačinska' genotypes can be used to select the most suited ones to be cultivated or used as parents in breeding programs; in this sense, genotypes II/2, III/9, III/13, and III/14 have good flower production and satisfactory pollen germination.

\section{Acknowledgements}

To the Ministry of Education, Science and Technological Development of the Republic of Serbia, for financial support.

\section{References}

ALBURQUERQUE, N.; BURGOS, L.; EGEA, J. Influence of flower bud density, flower bud drop and fruit set on apricot productivity. Scientia Horticulturae, v.102, p.397-406, 2004. DOI: 10.1016/j.scienta.2004.05.003. 
ANSARI, M.; DAVARYNEJAD, G. The flower phenology of sour cherry cultivars. American-Eurasian Journal of Agricultural and Environmental Sciences, v.4, p.117-124, 2008.

BEYER, M.; HAHN, R.; PESCHEL, S.; HARZ, M.; KNOCHE, M. Analysing fruit shape in sweet cherry (Prunus avium L.). Scientia Horticulturae, v.96, p.139-150, 2002. DOI: 10.1016/ S0304-4238(02)00123-1.

BURGOS, L.; ALBURQUERQUE, N.; EGEA, J. Flower biology in apricot and its implications for breeding. Spanish Journal of Agricultural Research, v.2, p.227-241, 2004.

CHANG, L.S.; IEZZONI, A.F.; FLORE, J.A. Yield components in 'Montmorency' and 'Meteor' sour cherry. Journal of the American Society for Horticultural Science, v.112, p.247-251, 1987.

DAVARYNEJAD, G.H.; ANSARI, M.; NYÉKI, J.; SZABO, Z. Seasonality of weather and phenology of reproductive organs of flower of sour cherry cultivars in Hungarian climatic conditions. International Journal of Horticultural Science, v.15, p.75-80, 2009.

DAVARYNEJAD, G.H.; SZABO, Z.; NYEKI, J.; SZABO, T. Phenological stages, pollen production level, pollen viability and in vitro germination capability of some sour cherry cultivars. Asian Journal of Plant Sciences, v.7, p.672-676, 2008. DOI: 10.3923/ ajps.2008.672.676.

EBERT, G. Fertilizing for high yield and quality: pome and stone fruits of the temperate zone. Basel: International Potash Institute, 2009.74p. (IPI. Bulletin, 19).

GARCIA-MONTIEL, F.; SERRANO, M.; MARTINEZ-ROMERO, D.; ALBURQUERQUE, N. Factors influencing fruit set and quality in different sweet cherry cultivars. Spanish Journal of Agricultural Research, v.8, p.1118-1128, 2010.

GUNES, N.T. Frost hardiness of some Turkish apricot cultivars during the bloom period. Hortscience, v.41, p.310-312, 2006.

HILLIG, K.W.; IEZZONI, A.F. Multivariate analysis of a sour cherry germplasm collection. Journal of the American Society for Horticultural Science, v.113, p.928-934, 1988.

HJALMARSSON, I.; ORTIZ, R. In situ and ex situ assessment of morphological and fruit variation in Scandinavian sweet cherry. Scientia Horticulturae, v.85, p.37-49, 2000. DOI: 10.1016/ S0304-4238(99)00123-5.

KODAD, O.; SOCIAS I COMPANY, R. Differential flower and fruit damages by spring frosts in almond. Nucis, v.12, p.5-7, 2004.

KODAD, O.; SOCIAS I COMPANY, R. Significance of flower bud density for cultivar evaluation in almond. HortScience, v.43, p.1753-1758, 2008.

MAGUYLO, K.; LANG, G.A.; PERRY, R.L. Rootstocks genotype affects flower distribution and density of 'Hedelfinger' sweet cherry and 'Montmorency' sour cherry. Acta Horticulturae, n.636, p.259-266, 2004.

MILUTINOVIĆ, M.; SIMONOVIĆ, J.; JOVANOVIĆ, M. Proučavanje klonova Oblačinske višnje. Jugoslovensko Voćarstvo, v.14, p.109-113, 1980.

NIKOLIĆ, D.; RAKONJAC, V.; MILUTINOVIĆ, M.; FOTIRIĆ, M. Genetic divergence of 'Oblačinska' sour cherry (Prunus cerasus L.) clones. Genetika, v.37, p.191-198, 2005. DOI: 10.2298/GENSR0503191N.

NYEKI, J.; SZABO, T.; SZABO, Z. Blooming phenology and fertility of sour cherry cultivars selected in Hungry. International Journal of Horticultural Sciences, v.8, p.33-37, 2002.

PÉREZ-SÁNCHEZ, R.; GÓMEZ-SÁNCHEZ, M.A.; MORALES-CORTS, R. Agromorphological characterization of traditional Spanish sweet cherry (Prunus avium L.), sour cherry (Prunus cerasus L.) and duke cherry (Prunus x gondouinii Rehd.) cultivars. Spanish Journal of Agricultural Research, v.6, p.42-55, 2008.

RADE, M.; ŽIKIĆ, M.; MITIĆ, N.; NIKOLIĆ, R. Identification and in vitro propagation of promising 'Oblačinska' sour cherry selections in eastern Serbia. Acta Horticulturae, n.795, p.159-162, 2008.

RAKONJAC, V.; AKIŠĆ, M.F.; NIKOLIĆ, D.; MILATOVIĆ, D.; ČOLIĆ, S. Morphological characterization of 'Oblačinska' sour cherry by multivariate analysis. Scientia Horticulturae, v.125, p.679-684, 2010. DOI: 10.1016/j. scienta.2010.05.029.

RAKONJAC, V.; NIKOLIĆ, D. Variability and path coefficient analysis of yield components in 'Oblačinska' sour cherry sub-clones. Journal of the American Pomological Society, v.62, p.30-35, 2008.

RODRIGO, J.; HERRERO, M. Effects of pre-blossom temperatures on flower development and fruit set in apricot. Scientia Horticulturae, v.92, p.125-135, 2002. DOI: 10.1016/ S0304-4238(01)00289-8.

RODRIGO, J.; HERRERO, M.; HORMAZA, J.I. Pistil traits and flower fate in apricot (Prunus armeniaca). Annals of Applied Biology, v.154, p.365-375, 2009. DOI: 10.1111/j.1744-7348.2008 $.00305 . \mathrm{x}$.

RUIZ, D.; EGEA, J. Analysis of the variability and correlations of floral biology factors affecting fruit set in apricot in a Mediterranean climate. Scientia Horticulturae, v.115, p.154-163, 2008. DOI: 10.1016/j.scienta.2007.08.016.

SOCIAS I COMPANY, R.; ALONSO, J.M.; APARISI, J.G. Fruit set and productivity in almond as related to self-compatibility, flower morphology and bud density. The Journal of Horticultural Science and Biotechnology, v.79, p.754-758, 2004.

SZPADZIK, E.; JADCZUK-TOBJASZ, E.; ŁOTOCKA, B. Floral biology of some sour cherry cultivars and their suitability for cultivation. Horticulture and Landscape Architecture, v.31, p.43-51, 2010.

SZPADZIK, E.; JADCZUK-TOBJASZ, E.; ŁOTOCKA, B. Preliminary evaluation of pollen quality, fertility relations and fruit set of selected sour cherry cultivars in polish conditions. Acta Agrobotanica, v.61, p.71-77, 2008.

TOSUN, F.; KOYUNCU, F. Investigations of suitable pollinator for 0900 Ziraat sweet cherry cv.: pollen performance tests, germination tests, germination procedures, in vitro and in vivo pollinations. Horticultural Science, v.34, p.47-53, 2007.

UNO, Y.; PRASHER, S.O.; LACROIX, R.; GOEL, P.K.; KARIMI, Y.; VIAU, A.; PATEL, R.M. Artificial neural networks to predict

Pesq. agropec. bras., Brasília, v.48, n.1, p.33-41, jan. 2013

DOI: $10.1590 / \mathrm{S} 0100-204 \mathrm{X} 2013000100005$ 
corn yield from Compact Airborne Spectrographic Imager data. Computers and Electronics in Agriculture, v.47, p.149-161, 2005. DOI: 10.1016/j.compag.2004.11.014.
WILLIAMS, R.R. Effect of summer nitrogen applications on quality of apple blossom. Journal of Horticultural Sciences and Biotechnology, v.40, p.31-41, 1965.

Received on June 26, 2012 and accepted on January 7, 2013 